\title{
Efektivitas Latihan Otot Dasar Panggul dalam Mencegah Konstipasi Pasien Stroke Non Hemoragik
}

\author{
Veroneka Yosefpa Windahandayani ${ }^{1}$, Yakobus Siswadi ${ }^{2}$, Emiliana Tijtra ${ }^{3}$ \\ ${ }^{1}$ Universitas Katolik Musi Charitas, Palembang, Indonesia \\ ${ }^{2}$ Universitas Pelita Harapan, Jakarta, Indonesia \\ ${ }^{3}$ STIK Sint Carolus, Jakarta, Indonesia \\ Alamat Korespondensi: veronikawinda@ukmc.ac.id
}

\begin{abstract}
Abstrak
Konstipasi banyak ditemukan pada pasien stroke non hemoragik. Konstipasi ini disebabkan oleh gangguan hubungan antara sistem saraf dan pencernaan akibat penyumbatan pembuluh darah otak oleh trombus atau embolus. Bahayanya adalah saat mengejan akibat konstipasi, terjadi peningkatan tekanan intra kranial, sehingga penting dilakukan pencegahan konstipasi. Tujuan penelitian ini adalah untuk menilai efektivitas latihan otot dasar panggul dalam mencegah konstipasi pada stroke non hemoragik. Penelitian ini menggunakan desain quasy experiment terhadap 66 subjek yang dipilih dengan teknik purposive sampling, masing-masing 33 subjek pada kelompok intervensi dan kelompok kontrol. Latihan otot dasar panggul dilakukan 3 kali sehari selama 3 hari dan dievaluasi pada hari ke-4, konstipasi diukur menggunakan Bristol Stool Chart. Berdasarkan uji statistic Chi-square, didapatkan bahwa ada perbedaan kejadian mencegah konstipasi subjek stroke non hemoragik, antar kelompok kontrol dan intervensi $(\mathrm{p}<0,05)$. Kesimpulannya adalah latihan otot dasar panggul efektif mencegah konstipasi pada subjek dengan stroke non hemoragik. Peneliti merekomendasikan pasien stroke non hemoragik untuk melakukan latihan otot dasar panggul secara rutin dengan bantuan keluarga.
\end{abstract}

Kata Kunci: konstipasi, latihan otot dasar panggul, stroke

\section{Effectiveness of Pelvic Floor Muscle Exercise to Prevent Constipation in Non-Hemorrhagic Stroke Patients}

\begin{abstract}
Constipation is commonly found in non-hemorrhagic stroke patients. Constipation is caused by disruption of the axis between the nervous and digestive systems, due to the blockage of the brain blood vessels by a thrombus or an embolus. Constipation may increase the intra cranial pressure, thus it is needed to be prevented. The purpose of this study was to assess the effectiveness of pelvic floor muscle exercises to prevent constipation in non-hemorrhagic strokes. This study used a quasy experimental design with 66 subjects selected by a purposive sampling technique. Subjects were divided into an intervention group (33 respondents) and a control group (33 respondents). Pelvic floor exercises were performed 3 times a day for 3 consecutive days and evaluated on the fourth day. Muscle constipation was measured using the Bristol Stool Chart. Based on the Chi-square statistical test, it was found that there was a difference in the incidence of constipation in non-hemorrhagic stroke subjects, between the control and intervention groups $(p<0.05)$. Pelvic floor muscle exercise is an effective intervention to prevent constipation in subjects with non-hemorrhagic strokes. We recommend non-hemorrhagic stroke patients to perform pelvic floor muscle exercise routinely with family's assistance.
\end{abstract}

Keywords: constipation, pelvic floor muscle exercises, stroke

How to Cite :

Windahandayani VY, Siswad Y, Tijtra E. Efektivitas Latihan Otot Dasar Panggul dalam Mencegah Konstipasi Pasien Stroke Non Hemoragik. J. Kdokt Meditek;27(1):16-21. Available from: $\quad$ http://ejournal.ukrida.ac.id/ojs/index.php/Meditek/article/view/1924. 


\section{Pendahuluan}

Stroke non hemoragik merupakan salah satu klasifikasi dari stroke yang disebabkan oleh oklusi arteri cerebral akibat, trombus atau embolus. ${ }^{1}$ Faktor prognosis penting dalam morbiditas dan mortalitas pasien stroke yaitu komplikasi yang terjadi. $^{2}$ Salah satu komplikasi adalah konstipasi. ${ }^{3}$

Lebih dari setengah pasien stroke di negaranegara Asia, mengalami konstipasi. Kasus konstipasi ditemukan sebanyak $76 \%$ dari 59 pasien stroke di Korea pada tahun 2015. Sama halnya dengan di Taiwan pada tahun 2013, dari 155 pasien stroke, ada 123 pasien yang mengalami konstipasi $(79 \%){ }^{3}$ Insiden konstipasi ini lebih sering terjadi pada pasien stroke non hemoragik, di mana dari 123 pasien stroke yang mengalami konstipasi, 77 $\%$ adalah pasien stroke non hemoragik. ${ }^{4}$

Konstipasi pasien stroke disebabkan oleh perubahan tingkat aktivitas yang membuat impuls saraf melambat dan penurunan peristaltik di usus besar, penurunan tonus dinding usus dan kekuatan abdomen berkurang, kesulitan menelan menyebabkan asupan cairan, serta asupan serat juga berkurang. Penggunaan obat juga memengaruhi fungsi usus sehingga mengalami dehidrasi, kebutuhan cairan untuk melunakkan feses tidak terpenuhi sehingga menyebabkan konstipasi. Alasan paling penting adalah cedera otak pada pasien stroke menyebabkan gangguan hubungan antara sistem saraf dan pencernaan, menyebabkan konstipasi. ${ }^{5}$ Gangguan koneksi menimbulkan masalah dengan otot panggul yang terlibat dalam buang air besar, seperti ketidakmampuan melemaskan otot-otot panggul, otot-otot panggul yang tidak mengoordinasikan relaksasi dan kontraksi dengan benar, disertai kelemahan pada otot panggul. Masalah otot panggul tersebut, dapat menyebabkan konstipasi kronis, hal ini sangat berbahaya bagi pasien stroke non hemoragik, karena dapat mengakibatkan peningkatan tekanan intra kranial saat mengejan akibat konstipasi. ${ }^{6}$ Oleh karena itu, diperlukan tindakan pencegahan agar tidak terjadi konstipasi.

Upaya mencegah agar tidak terjadi konstipasi merupakan peran perawat dalam memberikan asuhan keperawatan pada pasien stroke non hemoragik. Beberapa hal yang dapat dilakukan, yaitu dengan pemberian cairan 8 gelas $/$ hari, ${ }^{7}$ menganjurkan mengonsumsi serat buah dan sayur 20-30g/hari, edukasi beberapa latihan atau aktivitas fisik. $^{8-11}$ Latihan merupakan aktivitas yang dapat merangsang proses defekasi, salah satunya adalah latihan otot dasar panggul (Pelvic Floor Muscle Exercise). Latihan ini merupakan latihan yang sederhana, berfungsi memperlancar peredaran darah sehingga memberikan rangsangan pada serat saraf otot polos, menimbulkan metabolisme pada mitokondria, menghasilkan adenosine triphosphate (ATP). ${ }^{12}$ Adenosine triphosphate meningkatkan kontraksi otot dasar panggul, menguatkan otot perut dan otot dasar panggul, sehingga dapat merangsang peristaltik usus, akhirnya menimbulkan koneksi antara pencernaan dan sistem saraf untuk defekasi. ${ }^{9,13}$

Penelitian terdahulu menyebutkan bahwa latihan otot dasar panggul dapat mengurangi keluhan konstipasi. Hal ini terbukti dari hasil penelitian di mana dari 36 pasien, $90 \%$ melaporkan mengalami penurunan keluhan dari tanda dan gejala konstipasi. Tanda dan gejala tersebut adalah frekuensi buang air besar kurang dari 3 kali perminggu, sebelum latihan yaitu $39 \%$, setelah latihan menurun menjadi $5 \%$-value $<0,01$. Feses keras sebelum latihan yaitu $52,5 \%$, setelah latihan mengalami penurunan yaitu $0 \%, p$-value $<0,001$. Ukuran feses besar dan adanya hambatan sebelum latihan yaitu 50\%, setelah latihan menurun menjadi $2,5 \%, p$-value $<0,05 .^{14}$

Konstipasi menimbulkan rasa tidak nyaman meliputi keluhan perut terasa kembung, rasa sakit, adanya tekanan di perut, mengejan saat defekasi, serta ketidaknyamanan abdomen. ${ }^{11,15}$ Mencegah rasa tidak nyaman akibat konstipasi, diperlukan peran perawat dalam memberikan intervensi keperawatan. ${ }^{16}$ Intervensi latihan otot dasar panggul merupakan upaya membantu memenuhi rasa nyaman pada pasien. Teori keperawatan Comfort Theory, yang dikemukakan oleh Kathrine Kolcaba, menyebutkan ada tiga tipe Comfort Theory yaitu bantuan (relief), meringankan (ease), dan transendensi (transcendence). Comfort Theory ini ditujukan pada empat konteks yaitu kenyamanan fisik, psikospiritual, lingkungan, dan sosial. ${ }^{16}$

Penelitian tentang latihan otot dasar panggul untuk mencegah konstipasi pada stroke non hemoragik merupakan hal baru karena belum pernah dilakukan oleh peneliti terdahulu. Prosedur latihan otot dasar panggul ini biasanya diberikan pada pasien postpartum, dan pasien dengan masalah gangguan perkemihan. Lebih lanjut pada penelitian sebelumnya, lama waktu melakukan prosedur latihan selama 10-15 menit, lama waktu yang digunakan, dapat menimbulkan efek kelelahan pada pasien. Mencegah hal tersebut peneliti melakukan modifikasi waktu latihan, yang hanya dilakukan 4-5 menit. Hal ini yang membuat peneliti tertarik untuk melakukan penelitian latihan otot dasar panggul ini pada subjek stroke non hemoragik. 
Tujuan penelitian ini adalah, untuk menilai efektivitas latihan otot dasar panggul dalam mencegah konstipasi pada subjek stroke non hemoragik.

\section{Metodologi}

Desain pada penelitian ini adalah Quasy experiment. Besar sampel dihitung menggunakan aplikasi sample size calculator. ${ }^{17}$ Didapatkan jumlah sampel minimum 62 subjek. Untuk mengantisipasi kemungkinan adanya subjek drop out, maka ditambahkan 10\%. Jadi besar sampel dalam penelitian ini adalah 68 subjek. Masingmasing 34 subjek, untuk kelompok intervensi dan kelompok kontrol. Sebelum penelitian dilakukan, penelitian ini sudah mendapatkan lolos uji etik, dari komisi etik STIK Sint Carolus Jakarta, dengan nomor 120/Akd.ExtS2/STIK.SC/VII/2020.

Dalam pelaksanaan penelitian, sampel didapat 66 subjek, 33 subjek pada kelompok intervensi dan 33 subjek pada kelompok kontrol. Subjek yang didapat tidak mencapai 68 subjek, dikarenakan terdapat 2 subjek menolak untuk dilakukan penelitian karena takut tertular COVID-19.

Sampel didapatkan secara purposive yang harus memenuhi kriteria inklusi yaitu hasil pemeriksaan diagnostik menunjukan bahwa stroke non hemoragik, subjek 14-180 hari pascastroke, kondisi subjek sadar penuh, hemodinamik stabil, tidak ada keluhan sakit kepala, subjek mampu menggerakkan ekstremitas bawah, kedua ekstremitas bawah, atau sebagian. Sedangkan kriteria eksklusi dalam penelitian ini yaitu subjek stroke non hemoragik yang menggunakan obat pencahar atau enema, subjek tidak buang air besar $>3$ hari, subjek memiliki keluhan nyeri dan fraktur panggul.

Alat pengumpulan data yang digunakan adalah lembar catatan subjek, berisi tentang pertanyaan penelitian, diberikan pada subjek pada hari pertama penelitian dan Bristol stool form scale, sebagai parameter konstipasi, diberikan pada subjek di hari terakhir penelitian yaitu hari ke empat, sebagai evaluasi untuk menilai apakah latihan otot dasar panggul memiliki efek mencegah konstipasi atau tidak. Semua subjek penelitian ikut secara penuh dalam proses penelitian. Latihan otot dasar panggul, diberikan pada kelompok intervensi selama tiga hari, dan selanjutnya evaluasi dilakukan pada hari ke empat pada kelompok intervensi dan kontrol.

Analisis yang digunakan terhadap data yang telah diperoleh, menggunakan analisis univariat dan bivariat. Analisis univariat untuk mengetahui distribusi data subjek, dan analisis bivariat untuk mengetahui efektivitas dari latihan otot dasar panggul, mencegah konstipasi pasien stroke non hemoragik.

\section{Hasil}

\section{Karakteristik Subjek}

Tabel 1. Distribusi Subjek Berdasarkan Jenis Kelamin, Usia, Riwayat Konstipasi 1 Tahun Terakhir, Riwayat Tidak BAB >3 Hari Tahun 2020 (n=66)

\begin{tabular}{|c|c|c|c|c|c|}
\hline \multirow{3}{*}{ No } & \multirow{3}{*}{ Karakteristik } & \multicolumn{4}{|c|}{ Kelompok Penelitian } \\
\hline & & \multicolumn{2}{|c|}{ Intervensi } & \multicolumn{2}{|c|}{ Kontrol } \\
\hline & & $\mathrm{n}$ & $\%$ & $\mathrm{n}$ & $\%$ \\
\hline \multirow{3}{*}{1} & Jenis kelamin & & & & \\
\hline & Laki-laki & 22 & 66,7 & 23 & 69,7 \\
\hline & Perempuan & 11 & 33,3 & 10 & 30,3 \\
\hline \multirow{5}{*}{2} & Jumlah & 33 & 100 & 33 & 100 \\
\hline & Usia (tahun) & & & & \\
\hline & Usia Dewasa Madya (41-60) & 11 & 33,3 & 7 & 21,2 \\
\hline & Usia Dewasa $>60$ & 22 & 66,7 & 26 & 78,8 \\
\hline & Jumlah & 33 & 100 & 33 & 100 \\
\hline \multirow{3}{*}{3} & Riwayat konstipasi dalam 1 tahun terakhir & & & & \\
\hline & Ya & 28 & 84,8 & 27 & 81,8 \\
\hline & Tidak & 5 & 15,2 & 6 & 18,2 \\
\hline \multirow{5}{*}{4} & Jumlah & 33 & 100 & 33 & 100 \\
\hline & Riwayat tidak BAB > 3 hari & & & & \\
\hline & $\mathrm{Ya}$ & 15 & 45,5 & 14 & 42,4 \\
\hline & Tidak & 18 & 54,5 & 19 & 57,6 \\
\hline & Jumlah & 33 & 100 & 33 & 100 \\
\hline
\end{tabular}


Tabel 2. Perbedaan Kejadian Mencegah Konstipasi Subjek Stroke Non Hemoragik Sesudah Intervensi pada Kelompok Intervensi dan Kelompok Kontrol Tahun 2020 (n=66)

\begin{tabular}{|c|c|c|c|c|c|}
\hline \multirow[t]{3}{*}{ Mencegah Konstipasi } & \multicolumn{4}{|c|}{ Kelompok } & \multirow{3}{*}{$\begin{array}{c}\text { Nilai } \\
P\end{array}$} \\
\hline & \multicolumn{2}{|c|}{$\begin{array}{c}\text { Intervensi } \\
\mathrm{n}=33\end{array}$} & \multicolumn{2}{|c|}{$\begin{array}{c}\text { Kontrol } \\
\mathrm{n}=33\end{array}$} & \\
\hline & $\mathrm{n}$ & $\%$ & $\mathrm{n}$ & $\%$ & \\
\hline Tidak Konstipasi & 28 & 84,8 & 20 & 60,6 & 0,027 \\
\hline Konstipasi & 5 & 15,2 & 13 & 39,4 & \\
\hline
\end{tabular}

\section{Pembahasan}

\section{Analisis Univariat}

Tabel 1 menunjukan bahwa persentase, pada kelompok intervensi dan kelompok kontrol, jenis kelamin terbanyak adalah laki-laki. Usia terbanyak adalah usia dewasa $>60$ tahun, riwayat konstipasi dalam 1 tahun terakhir terbanyak adalah, memiliki riwayat konstipasi. Riwayat tidak $\mathrm{BAB}>3$ hari terbanyak adalah, tidak memiliki riwayat. Diet terbanyak adalah memiliki diet yang cukup, obat yang di konsumsi terbanyak adalah, mengonsumsi obat menyebabkan konstipasi, dan kebanyakan tidak memiliki penyakit penyerta.

Faktor risiko terjadinya stroke dibagi menjadi dua yaitu pertama, faktor risiko yang tidak dapat diubah seperti umur di atas 55 tahun, jenis kelamin pria, ras tertentu, dan genetik yang memiliki riwayat keluarga stroke (ayah, ibu, saudara sekandung, atau anak). Kedua, faktor risiko yang dapat diubah yaitu beberapa penyakit (hipertensi, diabetes melitus, obesitas, dislipidemia, atrial fibrilasi, stenosis arteri karotis, hiperfibrinogenemia, penyakit jantung lainnya, pasca stroke, anemia sickle cell, hiperhomosisteinemia), kurang aktivitas, migrain, penyalahgunaan obat, stress mental fisik, merokok, konsumsi alkohol, dan pemakaian kontrasepsi hormonal. ${ }^{18}$ Faktor risiko jenis kelamin sangat berhubungan dengan usia, pada usia muda, wanita memiliki risiko stroke yang sama tinggi atau lebih tinggi pada laki-laki, meskipun pada usia yang lebih tua risiko relatif sedikit lebih tinggi adalah laki-laki. Risiko stroke yang lebih tinggi wanita di usia muda, dikarenakan faktor kehamilan dan keadaan pascapartum, serta faktor hormonal, seperti penggunaan kontrasepsi hormonal. ${ }^{19}$

Hasil penelitian menunjukan, sebagian besar subjek berada pada kelompok usia $>60$ tahun. Usia merupakan faktor risiko terjadinya stroke, lebih banyak pada kelompok usia 55-64 tahun $(33,3 \%){ }^{20}$ Pasien stroke sering memiliki riwayat konstipasi yang dialami secara berulang. Riwayat penggunaan laksatif atau enema yang kronik dapat menyebabkan gangguan motilitas kolon dan perubahan struktur usus sehingga menyebabkan sering mengalami konstipasi. ${ }^{15}$

Riwayat konstipasi yang dialami subjek juga disebabkan kondisi subjek mengalami stroke non hemoragik di mana akan memengaruhi proses BAB. Lebih dari separuh subjek tidak memiliki riwayat tidak buang air besar (BAB) $>3$ hari. Artinya subjek bisa saja BAB 1 hari atau 2 hari sekali, akan tetapi subjek bisa disebut konstipasi. Frekuensi buang air besar lebih dari tiga hari, merupakan salah satu gejala dari konstipasi, tetapi bukan penentu bahwa subjek mengalami konstipasi. Terdapat tanda dan gejala lain yang juga menjadi penentu dari konstipasi yaitu perut kembung, sering buang angin, napas bau, sakit kepala, dan nyeri saat buang air besar. ${ }^{15,21}$ Kriteria Rome IV juga menyebutkan diagnosis konstipasi dipengaruhi oleh 2 atau lebih dari gejala yang ada, dalam kurun waktu 6 bulan, seperti gangguan pada proses defekasi, perubahan frekuensi $\mathrm{BAB}$, dan perubahan konsistensi feses. ${ }^{22}$

Hasil penelitian ini menunjukan, bahwa frekuensi BAB tidak dapat menunjukan bahwa subjek tersebut konstipasi akan tetapi dipengaruhi juga oleh perubahan konsistensi feses, perut kembung, sering buang angin, nyeri saat buang air besar, dan napas bau.

\section{Analisis Perbedaan Kejadian Mencegah Konstipasi Subjek Stroke Non Hemoragik Sesudah Intervensi}

Berdasarkan hasil uji yang dilihat pada tabel 2 pada kelompok kontrol dan intervensi didapatkan nilai p $0,027(<0,05)$. Hal ini membuktikan bahwa ada perbedaan antara kejadian konstipasi pada kelompok intervensi dan kontrol. Hasil penelitian ini sejalan dengan penelitian yang di lakukan Farahman (2015), ${ }^{14}$ di mana ditemukan perubahan frekuansi buang air besar pada minggu terakhir, dari 36 subjek konstipasi, 90\% melaporkan mengalami penurunan tanda dan gejala konstipasi. Tanda dan gejala konstipasi yang mengalami perubahan yaitu, frekuensi buang air besar kurang 
dari 3 kali per minggu, sebelum latihan $39 \%$, setelah latihan $5 \%$-value $<0,01$. Feses keras sebelum latihan $52,5 \%$, setelah latihan $0 \%$ p-value $<0,001$. Ukuran feses yang besar dan adanya hambatan $50 \%$, setelah latihan $2,5 \%$ p-value $<0,05$.

Intervensi latihan otot dasar panggul untuk mencegah konstipasi subjek stroke non hemoragik merupakan latihan sederhana yang dapat dilakukan oleh siapa saja dengan syarat sudah memahami prosedur latihan otot dasar panggul. Pada penelitian ini, peneliti melakukan intervensi latihan otot dasar panggul untuk mencegah konstipasi subjek stroke non hemoragik dengan waktu 4-5 menit 3 kali sehari dan terbukti efektif. Waktu penelitian ini sangat singkat dibandingkan dengan penelitian sebelumnya yaitu 10-15 menit. Latihan otot dasar panggul belum pernah dilakukan pada subjek dengan stroke non hemoragik sehingga merupakan kebaruan dari penelitian.

Subjek dengan stroke non hemoragik akan mengalami gangguan konstipasi disebabkan oleh karena adanya gangguan hubungan antara sistem saraf dan pencernaan akibat penyumbatan pembuluh darah otak oleh trombus atau embolus. Bahaya konstipasi pada subjek dengan stroke adalah saat mengejan karena dapat meningkatkan tekanan intra kranial yang berdampak pada perluasan area stroke bahkan bisa berujung pada kematian. Maka penting untuk dilakukan pencegahan konstipasi.

Latihan otot dasar panggul merupakan, salah satu aktivitas fisik yang dapat mencegah konstipasi. Latihan otot dasar panggul berkerja dengan memperlancar peredaran darah untuk meningkatkan pemenuhan nutrisi dan memberikan rangsangan pada serat saraf otot polos sehingga terjadi metabolisme pada mitokondria yang menghasilkan adenosine triphosphate (ATP). ${ }^{12}$ Energi yang dihasilkan meningkatkan kontraksi otot dasar panggul, dan memengaruhi fungsi rektum untuk memperlancar defekasi. ${ }^{12,23,24}$ Latihan otot dasar panggul juga dapat menguatkan otot perut dan otot dasar panggul, merangsang kontraksi alami otot-otot usus, meningkatkan peristalitk usus yang menggerakkan tinja lebih cepat sehingga menimbulkan defekasi. ${ }^{13}$ Kepatuhan terhadap program latihan otot dasar panggul menentukan keberhasilan latihan. ${ }^{24}$

Subjek yang mengalami konstipasi dapat menimbulkan ketidaknyamanan, karena rasa begah pada perut, nyeri saat proses defekasi, untuk itu intervensi latihan otot dasar panggul ini dilakukan untuk mengurangi rasa tidak nyaman pada subjek, karena konstipasi, teori keperawatan yang fokus untuk memberikan kenyamanan pada subjek adalah teorinya Kolkaba tentang comfort theory.
Kolcaba mendefinisikan, kenyamanan sebagai suatu keadaan telah terpenuhinya kebutuhan dasar manusia, kenyamanan merupakan pengalaman subjektif. ${ }^{25}$ Pada penelitian ini, subjek dengan stroke non hemoragik, yang teratur melakukan latihan otot dasar panggul selama 3 kali sehari yang dilakukan selama 3 hari dapat mencegah terjadinya konstipasi. Dalam proses penelitian subjek yang mengeluh begah, sakit saat buang air besar merasa lebih nyaman setelah melakukan latihan otot dasar panggul. Latihan otot dasar panggul ini dapat dijadikan pedoman, dalam melakukan intervensi keperawatan pasien stroke non hemoragik dalam mencegah konstipasi.

\section{Simpulan}

Latihan otot dasar panggul efektif mencegah konstipasi pasien stroke non hemoragik sehingga dapat dijadikan sebagai latihan mandiri secara berkelanjutan untuk mencegah terjadinya konstipasi. Pasien stroke non hemoragik juga perlu memperhatikan diet yang dikonsumsi termasuk cukup minum, serat, dan obat yang dikonsumsi. Pada program posyandu lansia dapat diberikan latihan otot dasar panggul, khususnya pada pasien stroke non hemoragik, sebagai pencegahan terjadinya konstipasi. Intervensi latihan otot dasar panggul merupakan evidence based practice nursing dalam intervensi keperawatan pasien stroke non hemoragik sehingga dapat dikenalkan pada peserta didik keperawatan.

\section{Ucapan Terima Kasih}

Peneliti mengucapkan banyak terimakasih kepada Universitas Katolik Musi Charitas Palembang sebagai pemberi dana dari proses penelitian, dan kepada pihak Puskesmas Rawabening yang telah memberikan izin dan membantu dalam pelaksanaan penelitian. Peneliti juga mengucapkan terimakasih kepada komisi etik STIK Sint Carolus, yang sudah memfasilitasi peneliti, agar penelitian ini layak etik.

\section{Daftar Pustaka}

1. Black JM, Hawks HJ. Keperawatan medikal bedah: manajemen klinis untuk hasil yang diharapkan. Edisi 8. Singapore: Elsevier; 2014.

2. Kim B, Lee J, Sohn MK, Kim DY. Risk factors and functional impact of medical complications in stroke. Ann Rehabil Med [Internet]. 2017;41(5):753-60. [cited 9 Nov 2019] Available from: 
https://www.ncbi.nlm.nih.gov/pmc/articles/P MC5698661

3. Lin C, Hung J, Cho C, Tseng C, Chen H, Lin $\mathrm{F}$, et al. Post stroke constipation in the rehabilitation ward : incidence, clinical course, and associated factors. Pubmed. 2013;54(11):624-9.

4. Lin K, Granger CL, Denehy L, Frawley HC. Pelvic floor muscle training for bowel dysfunction following colorectal cancer surgery: a systematic review. 2015;712:70312.

5. Li J, Yuan M, Liu Y, Zhao Y, Wang J, Guo W. Incidence of constipation in stroke patients. Medicine (Baltimore). 2016;(October):1-6.

6. Iffgd. About constipation. Int Found Gastrointest Disord [Internet]. 2019; [cited 23 Oct 2019] Available from: https://www.iffgd.org/advocate-for-digestivehealth

7. Kemenkes. Germas diet seimbang. [Internet]. 2018; [cited 23 Oct 2019] Available from: http://p2ptm.kemkes.go.id/infographic-p2ptm

8. Guyton A. Fisiologi manusia dan mekanisme penyakit. edisi 3. Jakarta: EGC; 2012.

9. The International Urogynecological Association (IUGA). Constipation [Internet]. Burnsville; 2017. [cited 02 Dec 2019] Available from: https://www.yourpelvicfloor.org/conditions

10. LeMone P, Burke MK, Bauldoff G. Keperawatan medikal bedah gangguan neurologi. Jakarta : EGC; 2017.

11. Smeltzer SC, Bare BG, Hinkle JL, Cheever KH. Brunner \& Suddarth's textbook of medical-surgical nursing. Edisi 12. Philadelphia: Lippincott Williams \& Wilkins; 2010.

12. Baert AL, Knauth M. Imaging pelvic floor disorders. In: Stoker J, Taylor SA, Delancey JOL, editors. Medical radiology diagnostic imaging. Heidelberg: Springer; 2010.

13. Clinicians from physical therapy and rehabilitation at center BIDMC. Constipation and the pelvic floor muscles. Esth Isr Deaconess Med Cent. 2016;1-4. [cited 19 Oct 2019] Available from: https://www.bidmc.org/centers-anddepartments
14. Farahman, Abedi, Dooki, Jalilian, Tabari. Pelvic floor muscle exercise for paediatric functional constipation. 2015;9(6):16-7. Journal of Clinical and Diagnostic Research [cited 28 Sep 2019] Available from: https://www.ncbi.nlm.nih.gov/pmc/articles/P MC4525569

15. LeMone P, Burke MK, Bauldoff G. Keperawatan medikal bedah: gangguan gastrointestinal. Edisi 5. Iskandar MT, editor. Jakarta: EGC; 2016.

16. Alligood MR. Pakar teori keperawatan. Singapura: Elsvier; 2017.

17. Relief application. Sample size calculator. Relief Application; 2018. [cited 23 Nov 2019] Available https://www.calculator.net/sample-sizecalculator.html

18. Kemenkes. Germas faktor risiko stroke. [Internet].2018 [cited 27 Dec 2019] Available from: http://p2ptm.kemkes.go.id/artikelsehat/germas-cegah-stroke

19. Boehme KA, Esenwa C, Elkind MSV. Stroke risk factors, genetics, and prevention. Stroke Compend. 2017 [cited 29 Oct 2019] Available from: https://www.ncbi.nlm.nih.gov/pmc/articles/P MC5321635

20. KemenKes RI. Infodatin stroke. Jakarta:Kemenkes; 2019. [cited 04 Dec 2019] Available from: https://pusdatin.kemkes.go.id/article/view/200 31000003/infodatin-stroke.html

21. Potter PA, Perry AG. Fundamental of nursing [Internet]. Edisi 4. America: Elsevier; 2017. [cited 19 Sep 2019] Available from: https://books.google.co.id/books

22. Ford C, Lacy BE, Talley NJ. Irritable bowel syndrome. New engl J Med. 2019;2566-78.

23. Pribakti. Dasar-dasar uroginekologi. Jakarta: Sagung Seto; 2011.

24. Baessler K, Schussler B, Burgio KL, Moore H, Norton PA, Stantion SL. Pelvic floor reeducation. Edisi 2. London: Springer- Verlag; 2012.

25. Kolcaba K. Comfort line [Internet]. 2019. [cited 20 Jan 2020] Available from: https://www.thecomfortline.com/ 